\title{
Pemberian Kombinasi Estrogen Progesteron dan Testosteron Meningkatkan Ekspresi Messenger Ribonucleaic Acid (mRNA) Reseptor Estrogen Alpha dan Androgen pada Vagina Tikus Wistar (Rattus norvegicus) Dewasa yang Diovarektomi
}

\author{
Luh Yenny Armayanti \\ Program Magister Ilmu Biomedik Universitas Udayana \\ armayanti61@gmail.com
}

\begin{abstract}
Diterima: 20 Juni 2016. Disetujui: 27 Juni 2016. Diterbitkan: Agustus 2016
ABSTRAK

Masa menopause merupakan suatu periode terjadinya penurunan sekresi hormon ovarium (estrogen, progesteron dan tetstosteron) dan disertai dengan penurunan ekpresi reseptor hormon seks steroid, khususnya resptor estrogen alpha dan androgen. Perubahan dramatis pada jumlah hormon ovarium menyebabkan terjadi atrofi vulvovaginal yang ditandai dengan vagina menjadi kering, atrofi, dypareunia, serta gangguan bangkitan seksual. Pemberian Hormone Replacement Therapy (HRT) sudah diketahui secara luas dapat meningkatkan integritas vagina pada multipel sel didalam berbagai lapisan, tetapi data mengenai efek pemberian HRT terhadap ekspresi reseptor seks steroid masih terbatas. Penelitian ini bertujuan untuk membuktikan bahwa kombinasi estrogen progesteron dan testosteron meningkatkan ekspresi messenger ribonucleaic acid (mRNA) reseptor estrogen alpha dan reseptor androgen pada tikus wistar (Rattus norvegicus) dewasa yang diovarektomi. Penelitian ini menggunakan rancangan True Experimental - Post Test Only Control Group Design yang dilakukan di Laboratorium Histologi Universitas Udayana dengan menggunakan 36 ekor Tikus Wistar dewasa (Rattus norvegicus) yang diovarektomi. Tikus dipilih secara random, kemudian dibagi menjadi dua kelompok. Kelompok pertama sebanyak 18 ekor (kontrol) diberikan diberikan 2,9 $\mathrm{ml}$ aquades per hari sedangkan kelompok kedua sebanyak 18 ekor (perlakuan) diberikan terapi hormon kombinasi estrogen $(11 \mu \mathrm{g} / \mathrm{hari})$, progesteron $(180 \mu \mathrm{g} / \mathrm{hari})$ dan testosteron (360 $\mathrm{mg} / \mathrm{hari}$ ) dalam 2,9 ml aquades. Pada hari ke-31, tikus diterminasi dan diambil jaringan vagina. Ekspresi mRNA ER $\alpha$ dan AR akan diukur dengan menggunakan metode real time PCR. Analisis komparasi dengan $t$-independence test pada data ekspresi mRNA ER $\alpha$ dan AR posttest menunjukkan hasil yang berbeda secara bermakna dengan nilai $p=0,001(p<0,05)$. Simpulan dari penelitian ini adalah pemberian kombinasi estrogen progesteron dan testosteron meningkatkan ekspresi messenger ribonucleaic acid (mRNA) reseptor estrogen alpha dan androgen pada vagina tikus wistar (Rattus Norvegicus) dewasa yang diovarektomi.
\end{abstract}

Kata Kunci: Estrogen, Progesteron, testosteron, mRNA, ER $\alpha, A R$.

\section{ABSTRACT}

Menopause is a period in which there is a decrease of the secretion of ovarian hormones (estrogen, progesterone, and testosterone) and accompanied by a decrease in the expression of sex steroid hormone receptor, especially estrogen receptor alpha (ER $\alpha)$ and androgen receptor (AR). These dramatic change will cause atrofivulvovaginal marked by vagina dryness, atrophy, dypareunia, as well as sexual arousal disorder. Hormone Replacement Therapy has been widely known can improve the integrity of the vagina in multiple cells in various layers, but there is little known about the effect of HRT on the expression of sex steroid hormone in vagina. This research was a True Experimental - Post Test Only Control Group Design and was conducted at the Laboratory of Histology of the University of Udayana using 36 ovarectomized adult Wistar rats (Rattus norvegicus). The rats was choosen by random and divided into two groups. The first group (control) was given 2.9 $\mathrm{ml}$ of distilled water per day while the second group (treatment) is given a combination of estrogen hormone therapy ( $11 \mu \mathrm{g} /$ day), progesterone $(180 \mathrm{mg} /$ day) and testosterone ( $360 \mathrm{mg} /$ day) in 2.9 $\mathrm{ml}$ of distilled water. On day 31, mice terminated and vaginal tissue were taken. mRNA expression of $E R \alpha$ and AR measured by using real time PCR method. Data were analysed with $t$-independence test. 
Exspression of ER $\alpha$ and AR mRNA for both group were statistically signicant with $p$ value 0,001 $(p<0,05)$. The Conclusions of this research was the combination of estrogen progesterone and testosterone increased the expression of messenger ribonucleaic acid (mRNA) estrogen receptor alpha and androgen receptors in ovarectomized adult Wistar rats (Rattus norvegicus).

Keywords: Estrogen, Progesterone, Testosterone, mRNA, ER $\alpha, A R$.

\section{PENDAHULUAN}

Perkembangan di dunia kedokteran dan meningkatnya kondisi sosial ekonomi telah berakibat pada peningkatan usia harapan hidup dan populasi wanita postmenopause. Jumlah wanita menopause di Asia pada tahun 2025 akan mencapai 373 juta jiwa. ${ }^{1}$ Pada tahun 2020, diperkirakan jumlah wanita menopause dengan usia rata-rata 49 tahun di Indonesia sebanyak 30,3 juta. $^{2}$ Berdasarkan data tersebut jelas bahwa jumlah wanita menopause akan terus meningkat setiap tahunnya yang disebabkan oleh meningkatnya usia harapan hidup penduduk Indonesia.

Pada wanita menopause akan muncul berbagai masalah kesehatan yang disebabkan oleh menurunnya sekresi hormon ovarium seperti estrogen, progesteron dan testosteron. Penurunan hormon ini juga diikuti dengan penurunan jumlah messenger ribonucleaic acid (mRNA) reseptor estrogen alpha $(E R \alpha)$ dan androgen (AR) yang menyebabnya kemampuan untuk menangkap hormon steroid menjadi menurun pada tikus. ${ }^{3}$ Penurunan jumlah sekresi hormon dan sintesa protein reseptornya menyebabkan terjadi masalah kesehatan yang meliputi gejala vasomotor, somatik, urogenital, psikologis, osteoporosis dan gangguan fungsi seksual. Masalah pada vagina diantaranya vagina menjadi kering, atrofi dan dypareunia, penurunan libido dan gangguan lubrikasi vagina merupakan gejala yang menyebabkan menurunnya kualitas seksual pada masa menopause. Durasi, berat ringan, dan pengaruh gejala-gejala atrofi vulvovaginal tersebut bervariasi dari individu satu dan lainnya. ${ }^{4}$

Atrofi vulvovaginal dapat terjadi kapan saja pada siklus kehidupan wanita, walaupun pada umumnya terjadi pada wanita menopause, pada saat terjadi kondisi hipoestrogenisme. ${ }^{5}$ Penyebab lain dari hipoestrogenisme adalah laktasi, pengobatan kanker payudara, dan pengobatan tertentu. Berbagai peneletian restrospektif telah mengevaluasi prevalensi atrofi vulvovaginal. Secara umum, prevalensi berkisar antara $4 \%$ pada menopause awal hingga $47 \%$ pada menopause akhir. Apabila tidak ditangani dengan baik, maka gejala ini akan menggangu kualitas seksual wanita menopause dan juga kualitas hidup secara keseluruhan. Keadaan ini dapat dikembalikan menjadi normal dengan pemberian Hormone Replacement Therapy baik berupa estrogen, progesteron, testosteron maupun kombinasi dari ketiga hormon tersebut. ${ }^{6}$

Efek endogen hormon steroid pada jaringan vagina dimediasi oleh reseptor steroid baik reseptor estrogen maupun androgen. ${ }^{7}$ Pada vagina wanita ditemukan adanya reseptor estrogen (ER $\alpha$ dan $\operatorname{Er} \beta)$, dan reseptor androgen baik untuk testosteron maupun DHT. Ekspresi dari masingmasing reseptor tersebut sangat dipengaruhi oleh usia, status menopause dan penggunaan terapi hormonal. Saat ini efek hormon steroid dalam pengaturan reseptor estrogen dan progesteron pada organ reproduksi telah ditelusuri secara luas, tetapi data mengenai ekspresi messenger ribonucleaic acid (mRNA) reseptor sex steroid hormone pada vagina masih terbatas. ${ }^{8}$

Terdapat perbedaan yang signifikan pada ekspresi ER $\alpha$ dan $\operatorname{Er} \beta$ antara wanita premenopause dan postmenopause, tetapi ekspresi $\operatorname{Er} \beta$ turun secara bermakna bahkan setelah pemberian estradiol. ${ }^{9}$ Reseptor androgen ditemukan pada vagina manusia yang memediasi aksi baik testosteron dan DHT. ${ }^{10}$ Ditemukan adanya korelasi negatif antara usia dan ekspresi AR pada mukosa vagina. Ovarektomi menyebabkan penurunan reseptor androgen (AR) baik bagian proksimal dan distal dan ekspresi meningkat setelah pemberian estrogen. ${ }^{11}$

Penggunaan estrogen dan progesteron untuk pengobatan pada menopause sudah umum diketahui. Pada penelitian ini peneliti ingin mengkombinasikan estrogen progesteron dan testosteron. Berdasarkan studi pendahuluan ditemukan bahwa pemberian estrogen $(11 \mu \mathrm{g} /$ hari $)$, progesteron $(180 \mu \mathrm{g} / \mathrm{hari})$ dan testosteron $(720 \mu \mathrm{g} /$ hari) meningkatkan integritas vagina dan juga ekspresi mRNA ER $\alpha$ dan AR. ${ }^{12}$

\section{BAHAN DAN METODE}

\section{Protokol Perlakuan Hewan Coba}

Penelitian ini menggunakan 36 ekor Tikus Wistar (Rattus norvegicus) betina dewasa, usia 2224 minggu dengan berat badan 200-250 gram. Tikus diperoleh dari Balai Besar Veterenier Denpasar. Penelitian dilakukan di Laboratorium Histologi Universitas Udayana. Tikus diberikan 
pakan secara ad libitum dan diadaptasi selama satu minggu sebelum dilakukan ovarektomi. Ovarektomi dilakukan dengan menggunakan anastesi terlebih dahulu. Dua minggu setelah ovarektomi, tikus dibagi menjadi dua kelompok secara acak yaitu kelompok kontrol dan perlakuan. Kelompok kontrol diberikan aquades 2,9 ml, kelompok perlakuan diberikan kombinasi

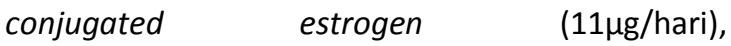
Medroxyprogesterone acetat $(180 \mu \mathrm{g} / \mathrm{hari})$, dan testosterone (andriol) $360 \mu \mathrm{g} /$ hari dalam 2,9 ml aquades. Pemberian hormon dilakukan dengan menggunakan sonde lambung selama 30 hari. Pada hari ke 31, tikus diterminasi dengan dilakukan anastesi terlebih dahulu, untuk mengambil jaringan vagina (2/3 posterior vagina).

\section{Persiapan Sampel}

Sampel jaringan dari hewan coba dipotong dengan ketebalan $5 \mathrm{~mm}$ seberat $20 \mathrm{mg}$ kemudian direndam dalam larutan RNAlater menggunakan tabung eppendorf dengan perbandingan 1:20 selama 24 jam dalam suhu $4^{\circ} \mathrm{C}$. Sampel diambil dari larutan kemudian dimasukkan ke dalam tabung eppendorf baru dan disimpan pada suhu $20^{\circ} \mathrm{C}$.

\section{Ekstraksi RNA}

Sampel diambil dan ditimbang (maksimal 15-20 mg). Sampel kemudian dihancurkan dan homogenisasi dan jaringan dimasukkan ke dalam tabung eppendorf, dengan menambahkan buffer RLT 600 ul, dan dihomogenisasi dengan jarum $20 \mathrm{G}$ minimal $5 x$ sedot-keluarkan. Lysate disentrifuge selama 3 menit dengan kecepatan penuh dan supernatant diambil secara hati-hati dan dimasukkan ke dalam tabung eppendorf baru dan ditambahkan ethanol 50\% 1:1. Campuran diambil (maksimal $700 \mathrm{ul}$, termasuk presipitat yang mungkin ada) ke dalam RNA spin column, lalu centrifuge 15 detik 8000 x g. 700 ul buffer RW1 ditambahkan ke dalam spin column, centrifuge selama 15 detik pada $8000 \times \mathrm{g}$, kemudian ditambahkan 500 ul buffer RPE ke dalam spin column, dan dicentrifuge 15 detik pada 8000 x g. Tambahkan 500 ul buffer RPE ke dalam spin column, centrifuge 2 menit pada $8000 \times$ g. Spin column dipindahkan ke dalam collection tube $2 \mathrm{ml}$ baru, centrifuge selama 1 menit pada kecepatan maksimal. Spin column dipindahkan pada tabung 1,5 ml, tambahkan 30-50 ul RNAase free-water langsung pada membrane spin column, centrifuge selama 1 menit pada 8000 x g. Simpan pada $-20^{\circ} \mathrm{C}$ sebelum dilanjutkan pada langkah berikutnya.

\section{Metode Kuantitatif Relatif 1-step qRT-PCR}

Kuantifikasi Relatif 1-step qRT-PCR dilakukan dengan menggunakan primer: Forward Gen Estrogen Receptor CCACTCAAGGGCAAGATGAT. Reverse Gen Estrogen Receptor GGGTTCAGCATTTCCAAAAA. Forward Gen Androgen Receptor GGAGAACTCTTCAGAGCAAG. Reverse Gen Androgen Receptor AGCTGAGTCATCCTGATCTG. Gen glyseraldehyde 3phospate dehydrogenase (GAPDH) digunakan sebagai normalisasi. Amplifikasi dilakukan dalam total volume $20 \mu \mathrm{l}$, terdiri dari 100 ng RNA dari sampel, Kapa Sybr Fast 2X, Kapa RT mix (50X), distilled water sampai 20 ul. Amplifikasi dilakukan pada mesin thermal cycler selama 40 siklus menggunakan protokol sebagai berikut: $42^{\circ} \mathrm{C}$ selama 5 menit, $95^{\circ} \mathrm{C}$ selama 5 menit, $95^{\circ} \mathrm{C}$ selama 3 detik, dan $60^{\circ}$ selama 20 detik.

\section{Analisis Data}

Data yang diperoleh dari hasil penelitian disajikan dalam bentuk grafik rata-rata ekspresi mRNA ER $\alpha$ dan AR pada kelompok kontrol dan perlakuan. Perbedaan rata-rata ekspresi mRNA $E R \alpha$ dan AR pada kelompok kontrol dan perlakuan diuji dengan menggunakan independent t-test dengan software SPSS 16.0 dengan $\mathrm{p}=0,05$.

\section{HASIL}

\section{Ekspresi mRNA ER $\alpha$}

Berdasarkan hasil analisis dengan menggunakan metode Real Time-PCR didapatkan hasil seperti disajikan dalam tabel berikut:

Tabel 1.

Ekspresi mRNA reseptor estrogen $\alpha(E R \alpha)$ pada Kelompok Kontrol dan Perlakuan

\begin{tabular}{lccc}
\hline $\begin{array}{c}\text { Ekspresi } \\
\text { mRNA ER } \boldsymbol{\alpha}\end{array}$ & $\mathbf{n}$ & Rerata $(\mathbf{n g} / \boldsymbol{\mu l})$ & SD \\
\hline kontrol & 18 & 0,39 & 0,22 \\
perlakuan & 18 & 4,05 & 0,82 \\
\hline
\end{tabular}

Dari Tabel 1, dapat diketahui bahwa rerata ekspresi mRNA ER $\alpha$ kelompok perlakuan adalah $4,05 \pm 0,82 \mathrm{ng} / \mu \mathrm{l}$ lebih tinggi dibandingkan kelompok kontrol yang memiliki rata-rata $0,39 \pm 0,22 \mathrm{ng} / \mu \mathrm{l}$. Perbedaan tersebut diuji dengan independent $t$-test dan signifikan secara statistik dengan nilai $p=0,001(p<0,05)$.

\section{Ekspresi mRNA AR}

Berdasarkan hasil analisis dengan menggunakan metode Real Time-PCR didapatkan hasil seperti disajikan dalam tabel berikut:

Tabel 2.

Ekspresi mRNA reseptor androgen (AR) pada Kelompok Kontrol dan Perlakuan 


\begin{tabular}{lccc}
\hline $\begin{array}{c}\text { Ekspresi } \\
\text { mRNA AR }\end{array}$ & $\mathrm{n}$ & Rerata $(\mathrm{pg} / \mu \mathrm{l})$ & $\mathrm{SD}$ \\
\hline kontrol & 18 & 7,01 & 1,34 \\
perlakuan & 18 & 17,85 & 1,86 \\
\hline
\end{tabular}

Dari tabel 2 dapat diketahui bahwa rerata ekspresi mRNA AR kelompok perlakuan adalah $17,85 \pm 1,86 \mathrm{pg} / \mu \mathrm{l}$ lebih tinggi dibandingkan kelompok kontrol dengan rata-rata 7,01 $\pm 1,34$ $\mathrm{pg} / \mu \mathrm{l}$. Efek pemberian kombinasi estrogen progesteron dan testosteron terhadap ekspresi mRNA AR dapat diketahui dengan melakukan pengujian terhadap perbedaan rerata ekspresi mRNA AR pada kelompok kontrol dan perlakuan dengan independent t-test. Hasil uji $T$ menunjukkan nilai $p=0,001(p<0,05)$ yang artinya perbedaan rerata ekspresi mRNA AR kelompok kontrol dan perlakuan signifikan secara statistik.

\section{DISKUSI}

Penurunan fungsi ovarium menyebabkan menurunnya sekresi hormon-hormon ovarium seperti estrogen, progesteron dan testosteron. Hal ini menyebabkan ovarium tidak mampu menjawab rangsangan hipofisis untuk menghasilnya hormon steroid. Jumlah FSH dan LH menjadi tinggi pada periode menopause. ${ }^{13}$

Penurunan konsentrasi estrogen dan androgen terutama pada masa menopause bukan hanya dikaitkan dengan perubahan dramatis pada struktur jaringan genital, termasuk jaringan saraf, dan juga respon fisiologis modulator. Defisiensi estrogen dan androgen juga menyebabkan penurunan ekspresi dari sex steroid receptors. ${ }^{14}$ Penurunan jumlah ekspresi sex steroid receptors menyebabkan penurunan kemampuan untuk menangkap estrogen dan androgen bebas dalam sirkulasi.

Berdasarkan hasil penelitian, rata-rata ekspresi mRNA ER $\alpha$ pada kelompok kontrol adalah $0,39 \pm 0,22 \mathrm{ng} / \mu \mathrm{l}$ sedangkan pada kelompok perlakuan sebesar $4,05 \pm 0,82 \mathrm{ng} / \mu \mathrm{l}$. Perbedaan ini signifikan secara statistik setelah diuji menggunakan uji T tidak berpasangan dengan nilai $p=0,001(p<0,05)$. Hasil ini menunjukkan bahwa kombinasi estrogen progesteron dan testosteron dengan dosis masing-masing $11 \mu \mathrm{g}, 180 \mu \mathrm{g}$, dan $360 \mu \mathrm{g} /$ hari meningkatkan ekspresi mRNA ER $\alpha$ pada vagina tikus Wistar (Rattus norvegicus) dewasa yang diovarektomi.

Pemberian estrogen lokal pada vagina menyebabkan peningkatan ekspresi reseptor estrogen alpha dan progesteron pada bagian posterior vagina wanita menopause sedangkan ekspresi reseptor estrogen beta tidak terlihat adanya perubahan. Fakta ini menjelaskan bahwa proliferasi jaringan vagina dimediasi oleh ER $\alpha .{ }^{15}$
Androgen reseptor merupakan salah satu reseptor seks steroid yang ditemukan pada vagina tikus. Ekspresi AR juga diregulasi oleh hormon seks steroid seperti estrogen, progesteron dan testosteron. Berdasarkan hasil penelitian, rata-rata ekspresi mRNA AR pada kelompok kontrol adalah $7,01 \pm 1,34 \mathrm{pg} / \mu \mathrm{l}$ sedangkan pada kelompok perlakuan sebesar $17,85 \pm 1,86 \mathrm{pg} / \mu \mathrm{l}$. Perbedaan ini signifikan secara statistik setelah diuji menggunakan uji T tidak berpasangan dengan nilai $p=0,001(p<0,05)$. Hasil ini menunjukkan bahwa kombinasi estrogen progesteron dan testosteron dengan dosis masing-masing $11 \mu \mathrm{g}, 180 \mu \mathrm{g}$, dan $360 \mu \mathrm{g} /$ hari meningkatkan ekspresi mRNA AR pada vagina tikus Wistar (Rattus norvegicus) dewasa yang diovarektomi.

Pertambahan usia menyebabkan peningkatan metilasi yang telah diduga menjadi kemungkinan mekanisme epigenetik yang berkontribusi terhadap penyakit terkait dengan aging process. $^{3}$ Metilasi promoter-CpG island semakin dipercaya sebagai salah satu perubahan molekular yang dapat diobservasi pada proses penuaan. Metilasi dari region yang kaya akan CpG pada bagian promoter gen merupakan perubahan epigenetik yang menyebabkan inaktivasi transkripsi gen tanpa berhubungan dengan abnormalitas gen.

Proses metilasi yang terjadi pada proses penuaan kemungkinan menyebabkan tidak terjadinya sintesis mRNA ER $\alpha$ yang menyebabkan ekspresi ER $\alpha$ menurun pada masa menopause. Peranan pemberian kombinasi estrogen progesteron dan testosteron adalah menghambat terjadi metilasi daerah CPG island di daerah promoter sehingga menghambat terjadi gene silencing dan merangsang terjadinya gene transcription. ${ }^{16}$

\section{SIMPULAN}

Berdasarkan hasil penelitian, dapat disimpulkan bahwa kombinasi estrogen progesteron dan testosteron meningkatkan ekspresi messenger ribonucleaic acid (mRNA) reseptor estrogen alpha dan reseptor androgen pada tikus wistar (Rattus norvegicus) dewasa yang diovarektomi.

\section{DAFTAR PUSTAKA}

1. WHO. Carcinogenicity of Combined Hormonal Contraceptive and Combined Menopausal Treatment. Switzerland: Departement of Reproductive Health and Research. 2005

2. Depkes R.I. Terjadi Pergeseran Umur Menopause. Available at: http://www.depkes.go.id/indeks.php.option=c 
Under Different Physiological and Treatment Condition. Int J Impot Res. 2013;25:7-11.

11. Traish, A.M., Kim, S.W., Stankovic, M., Goldstein, I., Kim, N.N. 2012. Testosterone Increases Blood Flow and Expression of Androgen and Estrogen Receptor in the Rat Vagina. J Sex Med. 2012: 4:609-619.

12. Armayanti, L.Y. "Pemberian Kombinasi Estrogen, Progesteron dan Testosteron Meningkatkan Ekspresi Messenger Ribonucleaic Acid (mRNA) reseptor Estrogen Alpha dan Androgen pada Vagina Tikus Wistar (Rattus norvegicus) Dewasa yang Diovarektomi"(Studi Pendahuluan). Denpasar: Universitas Udayana. 2016

13. Goodman, N.F., Cobin, R.H., Ginzburg, S.B., Katz, I. A., Woode, D.E. American Association of Clinical Endocrinologists Medical Guidelines for Clinical Practice for The Diagnosis and Treatment of Menopause. USA: AACE. 2011;17:4-25.

14. Traish, A.M., Kim, N.N. Modulation of Female Genital Sexual Arousal by Sex Steroid Hormones. London: Taylor \& Franci. 2006;6:181-192.

15. Fuermetz, A., Schoenfeld, M., Ennemoser, S., Muetzel, E., Jeschke, U., Jundth, K. Change of Steroid Receptor Expression in Posterior Vaginal Wall After Local Estrogen Therapy. J Obstet Gynecol Reprod Biol. 2015;187:40-45.

16. Simonetta, F., Lamon-Fava, S., Hyeran, J., Schaefer, E.J., Corrocher, R., Choi, S. Oestrogen Replacement Therapy Reduces Total Plasma Homocystein and Genomic DNA Methylation in Postmenopausal Women. British Journal of Nutrition. 2007;97:617-621 Obstetrics and Gynecology. 2001; 185:13251331.

10. Baldassare, M., Perrone, A.M., Giannone, F.A., Armillota, F., Battaglia, C., Costantino, A., Venturoli, S., Meriggiola, M.C. Androgen Receptor Expression in the Human Vagina 